\title{
Editorial
}

Obesity and Metabolic Syndrome

Diabetes Metab J 2019;43:156-157

https://doi.org/10.4093/dmj.2019.0057

pISSN 2233-6079 · eISSN 2233-6087

DIABET\&S \& METABOLISM JOURNAL

\section{Simply the Best: Anthropometric Indices for Predicting Cardiovascular Disease}

\author{
Jie-Eun Lee \\ Division of Endocrinology and Metabolism, Department of Internal Medicine, Hallym University Chuncheon Sacred Heart Hospital, Hallym University \\ College of Medicine, Chuncheon, Korea
}

As the prevalence of obesity increases, so does the burden of its associated comorbidities, such as myocardial infarction (MI) and ischemic stroke (IS). According to the Fact Sheet from the Korean Society for the Study of Obesity, medical expenses increase proportionally with body mass index (BMI) and waist circumference (WC) in both men and women [1]. Therefore, it is important to identify people at highrisk of obesity and its related comorbidities.

$\mathrm{BMI}$ is one of the most frequently used surrogate indicators ofobesity that reflects total body fat. However, both total body fat and fat distribution pattern are important when predicting the risk of cardiovascular diseases (CVD). The fat distribution pattern is determined by anthropometric measures, such as the WC, waist-to-hip ratio (WHR), waist-to-height ratio (WHtR), and sagittal abdominal diameter [2,3]. These anthropometric indices areassociated with, and may be predictors of, CVD [4-6], but these associations remain controversial.

At any given WC, Asian people have greater visceral fat compared with Europeans, and a tighter threshold of WC might be needed to determine the risk [7-9]. However, combining various ethnic groups under asingle "Asian" category might obscure important differences in groups. One study of about 15,000 Korean patients found no significant difference between WC and BMI in predicting the incidence of CVD [10], but a later study of 5,500 Koreans in 2009 found that WC and WHtR were superior to BMI [11].

The results of a recent study have important clinical significance for the Korean population. Using the data of more than
20 million Koreans from the National Health Insurance Service (NHIS), Cho et al. [12] confirmed that WC is a better marker for predicting the incidence of MI or IS than BMI. They also reported the appropriate WC cutoffs for predicting the risk of CVD; the optimal cutoffs were $84 / 85 \mathrm{~cm}$ for men (MI/IS, respectively) and $78 \mathrm{~cm}$ for women (both), which are lower than the current recommended cutoffs. In addition, the WC cutoff in the study by Cho et al. [12] is $10 \mathrm{~cm}$ lower than the global standard set by the World Health Organization for men [13]. These new values suggest that closer attention should be given to earlier identification and management of overweight/obesity for better CVD prevention. The study by Cho et al. [12] found smaller differences in the optimal cutoffs from the current recommendation in women. However, the authors noted that the incidence rates of MI or IS increases more steeply as WC increases [12]. Therefore, clinicians should be more alert to elevated abdominal circumference in both men and women.

Despite the possible differences from the actual incidence of CVD associated with the use of NHIS data and the relatively short follow-up period in the study by Cho et al. [12], this study included the largest number of Koreans to date, and its findings are of high clinical significance. Although BMI is still used as a standard to diagnose obesity, clinicians should be aware that a person with a 'high' WC, even when the BMI is in the 'healthy' range, may still have a higher risk of CVD.

WC is a non-invasive, easily measurable anthropometric index, but it is prone to technical error of measurement from in-
Corresponding author: Jie-Eun Lee (iD https://orcid.org/0000-0002-1039-5769 Division of Endocrinology and Metabolism, Department of Internal Medicine, Hallym University Chuncheon Sacred Heart Hospital, Hallym University College of Medicine, 77 Sakju-ro, Chuncheon 24253, Korea

E-mail: mdjelee@hallym.or.kr
This is an Open Access article distributed under the terms of the Creative Commons Attribution Non-Commercial License (http://creativecommons.org/licenses/by-nc/4.0/) which permits unrestricted non-commercial use, distribution, and reproduction in any medium, provided the original work is properly cited. 
ter-measurer error. Therefore, it would be clinically useful to compare WC alone with other anthropometric indices reflecting central obesity such as WHR or WHtR in predicting the incidence of CVD.

\section{CONFLICTS OF INTEREST}

No potential conflict of interest relevant to this article was reported.

\section{REFERENCES}

1. Korean Society for the Study of Obesity: Obesity fact sheet 2018. Available from: http://www.kosso.or.kr (cited 2019 Apr 2).

2. Kahn HS. Sagittal abdominal diameter predicts cardiovascular events. Nutr Metab Cardiovasc Dis 2017;27:1031-2.

3. Radholm K, Tengblad A, Dahlen E, Lanne T, Engvall J, Nystrom FH, Ostgren CJ. The impact of using sagittal abdominal diameter to predict major cardiovascular events in European patients with type 2 diabetes. Nutr Metab Cardiovasc Dis 2017; 27:418-22.

4. Guasch-Ferre M, Bullo M, Martinez-Gonzalez MA, Corella D, Estruch R, Covas MI, Aros F, Warnberg J, Fiol M, Lapetra J, Munoz MA, Serra-Majem L, Pinto X, Babio N, Diaz-Lopez A, Salas-Salvado J. Waist-to-height ratio and cardiovascular risk factors in elderly individuals at high cardiovascular risk. PLoS One 2012;7:e43275.

5. Janssen I, Katzmarzyk PT, Ross R. Waist circumference and not body mass index explains obesity-related health risk. Am J Clin Nutr 2004;79:379-84.

6. Schneider HJ, Friedrich N, Klotsche J, Pieper L, Nauck M, John U, Dorr M, Felix S, Lehnert H, Pittrow D, Silber S, Volzke H, Stalla GK, Wallaschofski $\mathrm{H}$, Wittchen HU. The predictive value of different measures of obesity for incident cardiovascular events and mortality. J Clin Endocrinol Metab 2010;95:1777-85.

7. Cheong KC, Ghazali SM, Hock LK, Subenthiran S, Huey TC, Kuay LK, Mustapha FI, Yusoff AF, Mustafa AN. The discriminative ability of waist circumference, body mass index and waist-to-hip ratio in identifying metabolic syndrome: variations by age, sex and race. Diabetes Metab Syndr 2015;9:74-8.

8. Demerath EW, Sun SS, Rogers N, Lee M, Reed D, Choh AC, Couch W, Czerwinski SA, Chumlea WC, Siervogel RM, Towne B. Anatomical patterning of visceral adipose tissue: race, sex, and age variation. Obesity (Silver Spring) 2007;15:2984-93.

9. Lear SA, Humphries KH, Kohli S, Chockalingam A, Frohlich JJ, Birmingham CL. Visceral adipose tissue accumulation differs according to ethnic background: results of the Multicultural Community Health Assessment Trial (M-CHAT). Am J Clin Nutr 2007;86:353-9.

10. Sung KC, Ryu S, Reaven GM; Health Screening Group at Kangbuk Samsung Hospital. Relationship between obesity and several cardiovascular disease risk factors in apparently healthy Korean individuals: comparison of body mass index and waist circumference. Metabolism 2007;56:297-303.

11. Park SH, Choi SJ, Lee KS, Park HY. Waist circumference and waist-to-height ratio as predictors of cardiovascular disease risk in Korean adults. Circ J 2009;73:1643-50.

12. Cho JH, Rhee EJ, Park SE, Kwon H, Jung JH, Han KD, Park YG, Park HS, Kim YH, Yoo SJ, Lee WY; Taskforce Team of the Obesity Fact Sheet of the Korean Society for the Study of Obesity. The risk of myocardial infarction and ischemic stroke according to waist circumference in 21,749,261 Korean adults: a nationwide population-based study. Diabetes Metab J 2019;43: 206-21.

13. World Health Organization. Waist circumference and waisthip ratio: report of a WHO expert consultation. Geneva: World Health Organization; 2011. 